\title{
A Proposed Model for the University Students' E-Portfolio
}

\author{
Omar M. K. Mahasneh \\ 'Department of Basic and Applied Science, Al-Shoubak University College, Al-Balqa Applied University, Jordan. \\ Email:Omar_mahasne@bau.edu.jo Tel:+962772060857
}

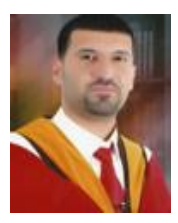

\begin{abstract}
Previous efforts have been made to develop a model for a university students' e-portfolio and determine university students' attitudes toward that model; however, to date, few studies have been conducted. This study employed a descriptive and experimental design: interviews with 20 specialists in educational science were conducted to develop and gain consensus on the proposed model for a university students' e-portfolio; and, following verification of its validity and reliability, a 17-item questionnaire was distributed among an experimental group of 90 students (43 male, 47 female) at Al-Shoubak University College to assess their attitudes toward the proposed e-portfolio model. The interviews resulted in a proposed model of a university students' e-portfolio comprising 10 components: student biography, course plan, reports and research, homework, projects and experiments, activities, summaries and conclusions, scientific material, audio and video clips, and samples of student performance. In addition, the results of the questionnaire revealed that the students' attitudes toward the proposed model were generally positive. Consequently, it is recommended that faculty members introduce the university students' e-portfolio into teaching practice.
\end{abstract}

Keywords: E-portfolio, university students, proposed model, Al-Shoubak University College, student learning evaluation, evaluation methods.

Citation | Omar M. K. Mahasneh (2020). A Proposed Model for the University Students' E-Portfolio. Journal of Education and eLearning Research, 7(1): 28-33.

History:

Received: 16 October 2019

Revised: 20 November 2019

Accepted: 23 December 2019

Published: 18 February 2020

Licensed: This work is licensed under a Creative Commons

Attribution 3.0 License (cc)

Publisher: Asian Online Journal Publishing Group
Funding: This study received no specific financial support.

Conflict of Interests: The author declares that there are no conflicts of interests regarding the publication of this paper.

Transparency: The author confirms that the paper is an honest, accurate, and transparent account of the study; no vital features of the study have been omitted; and that any discrepancies between the study conducted and as planned have been explained.

Ethical Standards: This study followed all ethical practices.

\section{Contents}

1. Introduction

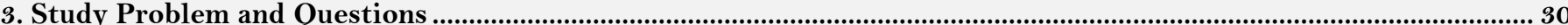

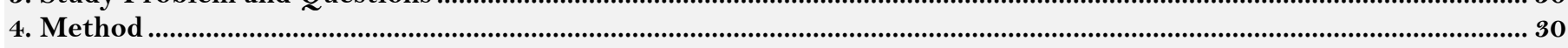

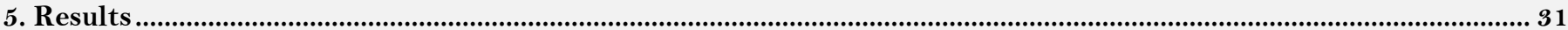

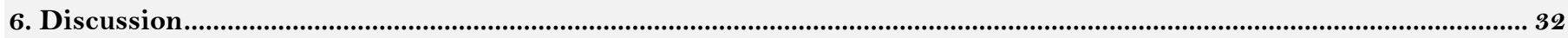

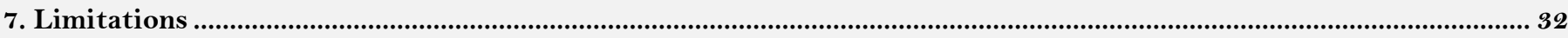

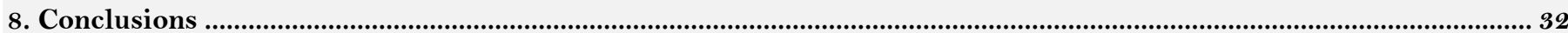

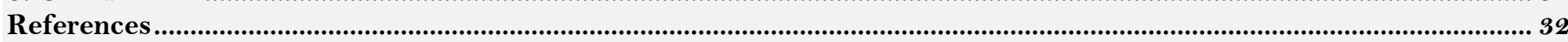




\section{Contribution of this paper to the literature}

This study contributes a model for a university students' e-portfolio for faculty members and students to use as part of the teaching-learning process. It includes the components of the eportfolio and emphasizes its importance as an evaluation tool for student learning.

\section{Introduction}

Following technological developments, particularly in communications, in the education field, it became necessary to integrate these innovations into the teaching process (Suskie, 2009). One of the most important was the e-portfolio, which has increased in significance (Smith and Tillema, 2007; Douglas et al., 2019) owing to its objectivity and effectiveness in evaluating learners' performance (Mahasneh and Farajat, 2015; Volmer and Sarv, 2018).

A theoretical literature review revealed that the term e-portfolio has become important in the teaching process. Several reasons were identified: increased use of computer technology; access to the Internet for educational purposes; and the development of a range of evaluation tools, from a simple appraisal of comprehension to an allinclusive assessment of knowledge, skills and emotional aspects, of which the e-portfolio is an example (Al Tawarah et al., 2017).

The e-portfolio is one technological innovation that has attracted the attention of educators. It enables the owner to electronically document their work and accomplishments over a number of years (Choi et al., 2005; Van Wyk, 2017). As such, an e-portfolio can contain the work of both the student and teacher in a particular subject over a specified period and be viewed in an electronic environment (Lopez-Fernandez and Rodriguez-Illera, 2009). Earlier definitions explained the e-portfolio as: a compilation of the best work produced by a student at each stage of their study (Lamont, 2004); and a repository of all information related to teachers' practice and the course (i.e., study plans, tests and assessment methods, models for student work, classroom pictures, philosophy and objectives, letters of recommendation, certificates, and favorite teachers) (Lambert et al., 2007). Furthermore, the American Association of Higher Education (AAHE) believes that the e-portfolio can be used to improve teaching in colleges of education and universities, becoming a requirement for obtaining a teaching license (Lamont, 2004).

Mahasneh and Murad (2014) conducted a study on whether e-portfolios should be part of school and university curricula, and the current study aimed to develop a model for a university students' e-portfolio.

\subsection{Theoretical Background}

The first use of the portfolio was by artists to collect their best work for later presentation and proof of their achievements and expertise. Bird (1990) stated that they maintained their portfolios for many years in their search for other work; however, the portfolio always included their best work, from which the concept of the achievement portfolio emerged in many fields. The portfolio first appeared in the education field in the late 1980s at colleges (Bird, 1990). Whereas that study focused on the need for quality, this concentrates on evaluation.

Stiggins (1994) defined the portfolio as a collection of a student's work that demonstrates their accomplishments for the purposes of assessment. In addition, Fenwick and Parsons (1999) explained that the information was selected by the student and took the various forms, including audio or video recordings.

There were many shortcomings with the traditional portfolio, which led to a difficult-to-use view despite the benefits. With the escalation of information technology and the potential to facilitate the educational process and data management, it was soon exploited to promote the use of the achievement portfolio; hence, the e-portfolio emerged (Gülbahar and Tinmaz, 2006; Meyer et al., 2010).

Ahn (2004) described the e-portfolio is the organization of a range of evidence selected from a complete inventory of what was learned at any given time. This chronological inventory is continually collected and maintained to present for comparison with others; this portfolio of all achievements can be web-based or burned to a CD for later occasional review and updating with new achievements for specific purposes (Evans, 1995).

E-portfolio are used by teachers and learners in pre-university education and faculty members and students at universities. It offers many benefits including: comprehensive performance assessment, exploiting technological developments, professional development, performance improvement, and stimulating creativity and innovation.

\subsection{Previous Studies Related to a University Students' E-Portfolio}

It appears no studies have been conducted on a possible model for a university students' e-portfolio or measuring their attitudes toward using them. Instead, studies have focused on defining the e-portfolio and its importance to the school-level teaching process, as well as investigating students' attitudes toward using an eportfolio. Some of these studies are discussed in this subsection.

Abo (2018) investigated the effectiveness of e-portfolios for improving teaching proficiency among student teachers at the Faculty of Education of Al Aqsa University, Gaza. Statistically significant differences $(\alpha=0.05$ were found between the scores in the sample population and the $75 \%$ cutoff value of the total available score on the e-portfolio evaluation card.

Meanwhile, Encalada et al. (2018) discovered that applying the lesson study model in combination with the eportfolio significantly improves learning achievements. It was found that, enabling asynchronous interaction, the eportfolio improves students' collaborative skills, and facilitates an understanding of functional elements at each stage of the model and their application in pre-professional practice.

In addition, Alsbai (2017) developed an e-portfolio for chemistry teaching and examined its effect on developing reflective thinking. Statistically significant differences $(\alpha=0.01)$ were indicated for reflective thinking in the experimental group: the e-portfolio proved very effective in improving reflective thinking.

Similarly, Alasale and Ayoup (2016), studying the effect of portfolios on fifth grade pupils' achievement trends in Arabic at government schools in Nablus, revealed a statistically significant mean difference between the experimental and control groups. In terms of dimensional achievement, this difference benefited the experimental group. 
Fuglík (2013) compared the e-portfolio initiatives, detailing their interconnections as well as possible applications in education in the Czech Republic.

Finally, Hasan (2005) showed the positive attitudes toward the use of e-portfolios among students at the Faculty of Education of Qatar University.

However, this study differs in being the only one to propose a model for a university students' e-portfolio and examine attitudes toward their use in the teaching process.

\section{Study Objectives}

This study aims to:

i) Propose a model for a university students' e-portfolio.

ii) Determine university students' attitudes toward the proposed model.

\section{Study Problem and Questions}

Based on personal experience of the lack of interest in keeping each semester's documents and record of activities by either faculty members or students, despite the emergence of (e)-portfolios since the early $20^{\text {th }}$ century, this study aimed to answer the following questions:

- Question 1: What model for a university students' e-portfolio can be developed?

- Question 2: What are university students' attitudes toward this model?

- Question 3: Is there a significant mean difference $(\alpha=0.05)$ between university students' attitudes toward the e-portfolio model and their gender?

\section{Method}

\subsection{Study Design}

The study adopted a descriptive and experimental design.

\subsection{Measures}

Table 4 in the Appendix shows the questionnaire designed to assess university students' attitudes toward the proposed e-portfolio model. Participants responded to each item using a 5-point scale, ranging from $1=$ completely disagree to $5=$ completely agree.

\subsection{Population and Sample}

The proposed e-portfolio model was developed from a consensus among 20 specialists in educational sciences. Students' attitudes toward the proposed e-portfolio model was determined through its use by an experimental group of 90 students at Al-Shoubak University College.

\subsection{Research Ethics}

Approval for the study was first sought from the Dean of Al-Shoubak University College, and then implementation agreed. The measurement tools were constructed, and their validity and reliability verified, before being used with the sample of participants.

\subsection{Measurement Tools}

1. An interview was conducted to develop a model for a university students' e-portfolio.

2. A questionnaire was distributed to assess students' attitudes toward the proposed model.

\subsection{Validity}

First, experts reviewed the language, clarity, relevance, and comprehensiveness of the questionnaire and interview items, each of which were rated as either 4-Very relevant, 3-Quite relevant, 2-Somewhat relevant, or 1 -Not relevant). The items were then divided into two groups: Group 1 comprised Categories 1 and 2, and Group 2, Categories 3 and 4. The content validity index (CVI) was calculated using the following formula:

$\mathrm{CVI}=$ Items rated as 4-Very relevant and 3-Quite relevant / Total number of items.

The CVI was 0.91 for the questionnaire and 0.92 for the interview, each falling within the accepted statistical range of $0.7-1$ ), confirming the validity of both.

\subsection{Reliability}

\subsubsection{Questionnaire Reliability}

A pilot was undertaken with 10 people, who did not participate in the later study. These results were used to calculate Cronbach's alpha coefficient and determine reliability. As shown in Table 1, the coefficient fell within the accepted statistical range of $0.7-1$ ), confirming the questionnaire to be reliable.

Table-1. Questionnaire reliability.

\begin{tabular}{c|c}
\hline Reliability statistics & \\
\hline Cronbach's alpha & Items (N) \\
\hline 0.822 & 17 \\
\hline
\end{tabular}

\subsubsection{Interview Reliability}

Four respondents were reinterviewed at a two-week interval, and $100 \%$ reliability was found between the first and final interviews. 


\subsection{Data Analysis}

SPSS Version 16.0 was used for the descriptive analysis. The mean and standard deviation were calculated to identify the respondents' attitudes toward the proposed e-portfolio model, and the t-test to determine the mean difference between their attitudes and their gender.

Having used a 5-point Likert scale, on which 5 indicated the highest and 1 the lowest scores, the mean range was calculated using the formula:

$$
\text { Mean Range }=(5-1) / 3=4 / 3=1.33
$$

\subsection{Data Interpretation}

University students' attitudes toward the proposed e-portfolio model were classified as follows: Positive for a mean range of 5-3.67) 5, Moderate for 3.66-2.33, and Negative for (2.32-0).

\subsection{Post-Study Design}

The study used a quasi-experimental one-group post-study design-E: X O.

\section{Results}

\subsection{Question 1}

To answer the question "What model for a university students' e-portfolio can be developed?" a literature review of previous educational studies and interviews with 20 specialists in educational sciences were conducted.

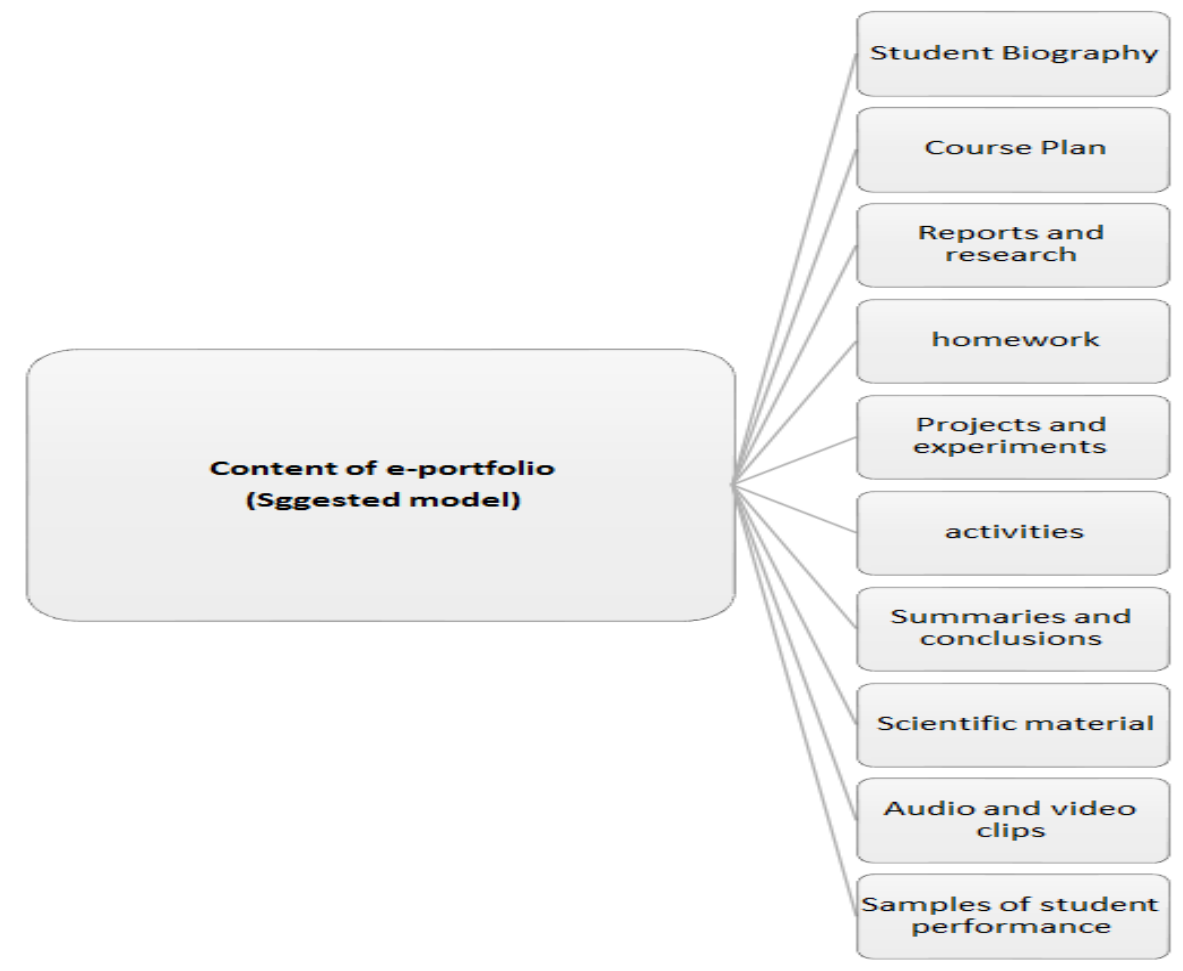

Figure-1. Proposed e-portfolio model.

Figure 1 shows the resulting model, which proposed a 10-component e-portfolio, as designed on Google Sites.

\subsection{Question 2}

To answer the question "What are university students' attitudes toward this model?" the mean and standard deviation were calculated.

Table-2. Mean and standard deviation for university students' attitudes.

\begin{tabular}{l|l|l|c|c|c}
\hline Rank & N & Statement & Mean & $\begin{array}{c}\text { Std. } \\
\text { Dev. }\end{array}$ & $\begin{array}{c}\text { Attitude } \\
\text { level }\end{array}$ \\
\hline 13 & 1 & Save my work and record it for future reference & 4.40 & 0.684 & Positive \\
\hline 17 & 2 & Demonstrate my creativity and organizational skills & 4.32 & 0.747 & Positive \\
\hline 3 & 3 & Undertake self-assessment & 4.78 & 0.667 & Positive \\
\hline 4 & 4 & Exploit a range of thinking skills to accomplish specific tasks & 4.73 & 0.445 & Positive \\
\hline 10 & 5 & Improve my computer skills & 4.53 & 0.502 & Positive \\
\hline 16 & 6 & Record my work in audio and video formats & 4.32 & 0.668 & Positive \\
\hline 15 & 7 & Conduct an objective evaluation by a faculty member & 4.38 & 0.990 & Positive \\
\hline 6 & 8 & Facilitate deletions, additions, and modifications & 4.66 & 0.876 & Positive \\
\hline 7 & 9 & Increase interest in the course & 4.60 & 0.493 & Positive \\
\hline 12 & 10 & Identify the strengths and weaknesses of the course & 4.47 & 0.502 & Positive \\
\hline 9 & 11 & Share my experiences with others & 4.53 & 0.674 & Positive \\
\hline 2 & 12 & Publish my experiences on web pages for others' benefit & 4.96 & 0.207 & Positive \\
\hline 1 & 13 & Increase my self-confidence & 4.97 & 0.181 & Positive \\
\hline 5 & 14 & Take advantage of services offered by websites & 4.71 & 0.456 & Positive \\
\hline 14 & 15 & Enhance my acquisition of course competencies & 4.39 & 1.148 & Positive \\
\hline 11 & 16 & Increase my knowledge and comprehension of course & 4.50 & 0.851 & Positive \\
\hline 8 & 17 & Exploit leisure time for design and research & 4.60 & 0.667 & Positive \\
\hline Overall attitude & 4.58 & Positive \\
\hline
\end{tabular}


According to the results shown in Table 2, university students' attitudes were generally positive $(\mathrm{m}=4.58)$. This implies that the e-portfolio employs modern methods that students have not previously used during their studies.

\subsection{Question 3}

To answer the question "Is there a significant mean difference $(\alpha=0.05)$ between university students' attitudes toward the e-portfolio model and their gender?" a t-test was performed.

Table-3. Results of t-test for effect of gender on university students' attitudes toward the e-portfolio model.

\section{Independent Samples t-test}

\begin{tabular}{|c|c|c|c|c|c|c|c|c|c|c|}
\hline & & \multicolumn{2}{|c|}{$\begin{array}{c}\text { Levene's test } \\
\text { for equality of } \\
\text { variances }\end{array}$} & \multicolumn{7}{|c|}{ t-test for equality of means } \\
\hline & & \multirow{2}{*}{$\begin{array}{c}\text { F- } \\
\text { value }\end{array}$} & \multirow[b]{2}{*}{ p-value } & \multirow[b]{2}{*}{ t-value } & \multirow[b]{2}{*}{ df } & \multirow{2}{*}{$\begin{array}{l}\text { p-value } \\
\text { (2-tailed) }\end{array}$} & \multirow{2}{*}{$\begin{array}{c}\text { Mean } \\
\text { difference }\end{array}$} & \multirow{2}{*}{$\begin{array}{c}\text { Standard } \\
\text { error of } \\
\text { difference }\end{array}$} & \multicolumn{2}{|c|}{$\begin{array}{c}95 \% \text { confidence interval } \\
\text { of difference }\end{array}$} \\
\hline & & & & & & & & & Lower & Upper \\
\hline \multirow[t]{2}{*}{ Total } & $\begin{array}{c}\text { Equal variances } \\
\text { assumed }\end{array}$ & 21.409 & 0.000 & 5.714 & 88 & 0.000 & 6.09154 & 1.06608 & 8.21014 & 3.97293 \\
\hline & $\begin{array}{c}\text { Equal variances } \\
\text { not assumed }\end{array}$ & & & 5.515 & 50.991 & 0.000 & 6.09154 & 1.10462 & 8.30916 & 3.87392 \\
\hline
\end{tabular}

\section{Group statistics}

\begin{tabular}{c|c|c|c|c|c}
\hline & Gender & N & Mean & Std. Dev. & Standard error of mean \\
\hline \multirow{2}{*}{ Total } & Male & 43 & 74.6744 & 6.88242 & 1.04956 \\
\cline { 2 - 6 } & Female & 47 & 80.7660 & 2.36103 & 0.34439 \\
\hline
\end{tabular}

Table 3 shows the results of the t-test, which revealed statistical significance $(\mathrm{F}=21.41, \mathrm{p}=0.000)$. With a smaller significance than the standard $(p=0.05)$, a significant mean difference $(\alpha=0.05)$ between students' attitudes and their gender were confirmed this was particularly true with regard to women (mean $=80.76$ ), which could be attributed to their interest in accomplishing their goals and recording their achievements for future reference.

\section{Discussion}

This study aimed to develop a university students' e-portfolio model and determine their attitudes toward the proposed e-portfolio. In accordance with the findings of Hasan (2005), students attitudes were generally positive, due to a group of influences of which the most important were:

1. The novelty of the study.

2. Students' first experience of preparing an e-portfolio for school or university.

3. The opportunity for students to demonstrate their achievements, creativity, and self-evaluation not usually offered by school or university teaching practices.

In addition, gender influenced university students' attitudes toward the e-portfolio model, particularly women, possibly due to their interest in accomplishing their goals and recording their achievements.

The findings of this study are consistent with those of others (Çimer, 2011; Abo, 2018). The e-portfolio is can indicate not only a student's academic level but also their aptitude and aspirations, as long as the tutor is adaptable and embraces creativity and diversity.

\section{Limitations}

To elicit accurate results, the study was conducted under normal conditions and, to avoid self-selection, efforts were made to ensure the sample population sufficiently represented all the classes at Al-Shoubak University College during the first semester of the 2019/2020 academic year. These results were verified by the validity and reliability of the tools used to collect the data. However, both this methodology and the way in which the results were interpreted may have placed limitations on the study.

\section{Conclusions}

In conclusion, the proposed model for a university students' e-portfolio consists of ten components: student biography, course plan, reports and research, homework, projects and experiments, activities, summaries and conclusions, scientific material, audio and video clips, and samples of student performance. Moreover, students' attitudes toward this model were positive.

\section{References}

Abo, M.H., 2018. The effectiveness of using E-portfolio on developing some of teaching proficiencies for teacher-students at the faculty of Education in Al-Aqsa University-Gaza. Master Thesis, Faculty of Education, Al-Aqsa University, Jerusalem.

Ahn, J., 2004. Electronic portfolios: Blending technology, accountability \& assessment. T.H.E. Journal, 31 (9).

Al Tawarah, H.M., O.M. Mahasneh and N.A. Al-Hawartheh, 2017. The effect of practical presentations' strategy on the achievement of the Ninth Graders students of the pre-vocational education subject in Shobak District Schools. International Education Studies, $10(5)$ : 109-1 14.Available at: https://doi.org/10.5539/ies.v10n5p109.

Alasale, A. and A. Ayoup, 2016. The effect of using portfolio on the achievement and trends of basic fifth grade pupils in the Arabic subject in the governmental schools in the city of Nablus. Master Thesis, Faculty of Education, An-Najah National University, Palestine.

Alsbai, Q., 2017. Designing e-portfolio in teaching chemistry and measuring its effect on developing reflective thinking skills among the second graders of secondary stage. International Journal of Educational Specializatio, 6(5): 17-28. 
Bird, T., 1990. The schoolteachers portfolio: An essay on possibilities. In Millman, J. \& Hammond, L.,(Eds.), The New Handbook of Teacher Evaluation: Assessing Elementary and Secondary School Teachers. 2nd Edn., Newbury Park, CA: Sage. pp: 241-256.

Choi, I., S. Land and A. Turgeon, 2005. Scaffolding peer-questioning strategies to facilitate metacognition during online small group discussion. Instructional Science, 33(5-6): 483-511.

Çimer, S.O., 2011. The effect of portfolios on students' learning: Student teachers' views. European Journal of Teacher Education, 34(2): 161176.Available at: https://doi.org/10.1080/02619768.2011.552183.

Douglas, M.E., S. Peecksen, J. Rogers and M. Simmons, 2019. College students' motivation and confidence for eportfolio use. International Journal of ePortfolio, 9(1): 1-16.

Encalada, K., J. Santiesteban, Y. Portela, S. Cruz and M. Arboleda, 2018. The development of e-portfolio for lesson study. IEEE Network.

Evans, S., 1995. Professional portfolio: Documenting and presenting performance excellence. Virginia Beach, V A: Teachers Little Secrets.

Fenwick, T. and J. Parsons, 1999. A note on using portfolio to assess learning. Canadion Social Studies, 33(3): 90-92.

Fuglík, F., 2013. Carried out a study aimed to use of e-portfolios in education. ICTE Journal, 2(1): 5-16.

Gülbahar, Y. and H. Tinmaz, 2006. Implementing project-based learning and e-portfolio assessment in an undergraduate course. Journal of Research on Technology in Education, 38(3): 309-327.Available at: https://doi.org/10.1080/15391523.2006.10782462.

Hasan, I., 2005. Attitudes of students of the Faculty of Education at Qatar University towards the preparation of a file E-student portfolio and its use in education and their views towards it. Conference Scientific Tenth - E-Learning Technology and Total Quality Requirements, Egypt, C. 1, pp: 31-67.

Lambert, C., J. Depaepe, L. Lambert and D. Anderson, 2007. E-portfolios in action, Kappa Delta Pi record. Indianapolis, KAPPA DELTA PI. International Honor Society in Education, 43(2): 76-81.

Lamont, M., 2004. What Are the features of E-portfolio implementation that can enhance learning and promote self- regulation? New Zealand: University of Wellington. P: 10

Lopez-Fernandez, O. and J.L. Rodriguez-Illera, 2009. Investigating university students' adaptation to a digital learner course portfolio. Computers \& Education, 52(3): 608-616.Available at: https://doi.org/10.1016/j.compedu.2008.1 1.003.

Mahasneh, O. and A. Farajat, 2015. The effectiveness of a training program based on practice of careers in vocational interes ts development. Journal of Education and Practice, 6(26): 101-108.

Mahasneh, O.M. and O.S. Murad, 2014. Suggested model (related to the student portfolio) used in evaluation the students in university courses. Higher Education Studies, 4(3): 72-81.Available at: https://doi.org/10.5539/hes.v4n3p72.

Meyer, E., P. Abrami, C. Wade, O. Aslan and L. Deault, 2010. Improving literacy and metacognition with electronic portfolios: Teaching and learning with epearl. Journal of Computers \& Education, 55(1): 84-91.

Smith, K. and H. Tillema, 2007. Use of criteria in assessing teaching portfolios: Judgemental practices in summative evaluation. Scandinavian Journal of Educational Research, 51(1): 103-117.Available at: https://doi.org/10.1080/003 13830601078696.

Stiggins, J., 1994. Student-centered classroom assessment. USA: Merrill Publishing Company. pp: 477.

Suskie, L., 2009. A assessing student learning: A common sense guide. 2nd Edn., US: Jossey Bass: Jossey- Bass Higher and Adult Education Series.

Van Wyk, M.M., 2017. Student teachers' views regarding the usefulness of reflective journal writing as an eportfolio alternative assessment strategy: An interpretive phenomenological analysis. Gender and Behaviour, 15(4): 10208-10219.

Volmer, D. and A. Sarv, 2018. E-portfolio as an effective tool for self-directed and reflective learning in social pharmacy. Research in Social and Administrative Pharmacy, 14(8): e43-e44.Available at: https://doi.org/10.1016/j.sapharm.2018.05.084.

\section{Appendix}

Table-4. Results of questionnaire on students' attitudes toward e-portfolio model

\begin{tabular}{|c|c|c|c|c|c|c|}
\hline $\mathbf{N}$ & Statement & \multicolumn{5}{|l|}{ Scale } \\
\hline \multicolumn{2}{|c|}{ E-portfolio helps to: } & $\begin{array}{l}\text { Completely } \\
\text { agree }\end{array}$ & Agree & Undecided & Disagree & $\begin{array}{l}\text { Completely } \\
\text { disagree }\end{array}$ \\
\hline 1 & $\begin{array}{l}\text { Save my work and record it for future } \\
\text { reference }\end{array}$ & & & & & \\
\hline 2 & $\begin{array}{l}\text { Demonstrate my creativity and } \\
\text { organizational skills }\end{array}$ & & & & & \\
\hline 3 & Undertake self-assessment & & & & & \\
\hline 4 & $\begin{array}{l}\text { Exploit a range of thinking skills to } \\
\text { accomplish specific tasks }\end{array}$ & & & & & \\
\hline 5 & Improve my computer skills & & & & & \\
\hline 6 & Record my work in audio and video formats & & & & & \\
\hline 7 & $\begin{array}{l}\text { Conduct an objective evaluation by a faculty } \\
\text { member }\end{array}$ & & & & & \\
\hline 8 & $\begin{array}{l}\text { Facilitate deletions, additions, and } \\
\text { modifications }\end{array}$ & & & & & \\
\hline 9 & Increase interest in the course & & & & & \\
\hline 10 & $\begin{array}{l}\text { Identify the strengths and weaknesses of the } \\
\text { course }\end{array}$ & & & & & \\
\hline 11 & Share my experiences with others & & & & & \\
\hline 12 & $\begin{array}{l}\text { Publish my experiences on web pages for } \\
\text { others' benefit }\end{array}$ & & & & & \\
\hline 13 & Increase my self-confidence & & & & & \\
\hline 14 & $\begin{array}{l}\text { Take advantage of services offered by } \\
\text { websites }\end{array}$ & & & & & \\
\hline 15 & $\begin{array}{l}\text { Enhance my acquisition of course } \\
\text { competencies }\end{array}$ & & & & & \\
\hline 16 & $\begin{array}{l}\text { Increase my knowledge and comprehension } \\
\text { of course }\end{array}$ & & & & & \\
\hline 17 & Exploit leisure time for design and research & & & & & \\
\hline
\end{tabular}

Asian Online Journal Publishing Group is not responsible or answerable for any loss, damage or liability, etc. caused in relation to/arising out of the use of the content. Any queries should be directed to the corresponding author of the article. 